\title{
Hydrogen Sulfide Is Produced in Response to Neuronal Excitation
}

\author{
Ko Eto, Miki Ogasawara, Ken Umemura, Yasuo Nagai, and Hideo Kimura \\ National Institute of Neuroscience, National Center of Neurology and Psychiatry, Kodaira, Tokyo 187-8551, Japan
}

Although hydrogen sulfide $\left(\mathrm{H}_{2} \mathrm{~S}\right)$ is generally thought of in terms of a poisonous gas, it is endogenously produced in the brain. Physiological concentrations of $\mathrm{H}_{2} \mathrm{~S}$ selectively enhance NMDA receptor-mediated responses and alter the induction of hippocampal long-term potentiation (LTP). Here we use cystathionine $\beta$-synthase (CBS) knock-out mice to clearly show that CBS produces endogenous $\mathrm{H}_{2} \mathrm{~S}$ in the brain and that $\mathrm{H}_{2} \mathrm{~S}$ production is greatly enhanced by the excitatory neurotrans-

Hydrogen sulfide $\left(\mathrm{H}_{2} \mathrm{~S}\right)$ is a well known toxic gas, and most studies about $\mathrm{H}_{2} \mathrm{~S}$ have been devoted to its toxic effects (Reiffenstein et al., 1992). However, relatively high endogenous levels of $\mathrm{H}_{2} \mathrm{~S}$ have been measured in the brains of rats, humans, and bovine (Goodwin et al., 1989; Warenycia et al., 1989; Savage and Gould, 1990), suggesting that $\mathrm{H}_{2} \mathrm{~S}$ may have a physiological function. Endogenous $\mathrm{H}_{2} \mathrm{~S}$ can be formed from L-cysteine by pyridoxal-5'-phosphate-dependent enzymes, including cystathionine $\beta$-synthase (CBS) (Stipanuk and Beck 1982; Griffith, 198 Swaroop et al., 1992). CBS is expressed in the brain, and the CB. inhibitors hydroxylamine and amino-oxyacetate suppre othe production of $\mathrm{H}_{2} \mathrm{~S}$, whereas the $\mathrm{CBS}$ activator methionine (SAM) enhances $\mathrm{H}_{2} \mathrm{~S}$ production. $\mathrm{P}$ siolo al concentrations of $\mathrm{H}_{2} \mathrm{~S}$ specifically potentiate the c ity of YDA receptor and alter the induction of long-tery poten tion (LTP) in the hippocampus (Abe and Kimura 996). cAMMmediated pathways may be involved in the modu tion of NMDA receptor by $\mathrm{H}_{2} \mathrm{~S}$ (Kimura, 2000). $\mathrm{H}_{2} \mathrm{~S}$ cap ${ }^{-1}$ o vulat the release of corticotropin-releasing hormon from the $h_{\text {s }}$ othalamus (Russo et al., 2000). Based on these on ery in heen proposed that $\mathrm{CBS}$ can produce $\mathrm{H}_{2} \mathrm{~S}$ in the $\mathrm{b}$, in and that $\mathrm{H}_{2} \mathrm{~S}$ may function as a neuromodulator (Abe and Kima, 1996).

Two other gases, nitric oxide (NO) and carbon monoxide (CO), are endogenously produced by enzymes localized in the brain (Maines, 1988; Palmer et al., 1988; Verma et al., 1993). Both $\mathrm{NO}$ and $\mathrm{CO}$ have been proposed as retrograde messengers in hippocampal LTP, a synaptic model of learning and memory (O’Dell et al., 1991; Schuman and Madison, 1991; Haley et al., 1992; Bliss and Collingridge, 1993; Stevens and Wang, 1993; Zhuo et al., 1993). The activities of NO synthase are regulated by $\mathrm{Ca}^{2+} /$ calmodulin, and NO is released when NMDA receptors

Received Dec. 28, 2001; revised Feb. 8, 2002; accepted Feb. 12, 2002.

This work was supported by a grant from National Institute of Neuroscience/ National Center of Neurology and Psychiatry (H.K.) and National Institutes of Health Grant 5R21GM57504. We thank Dr. J. P. Kraus for a CBS cDNA plasmid and Dr. N. Maeda for the information of three PCR primers to determine the genotype of CBS knock-out mice. We also thank Dr. D. Schubert for the critical reading of this manuscript.

Correspondence should be addressed to Dr. Hideo Kimura, National Institute of Neuroscience, National Center of Neurology and Psychiatry, 4-1-1 Ogawahigashi, Kodaira, Tokyo 187-8551, Japan. E-mail: kimura@ncnp.go.jp.

Copyright (C) 2002 Society for Neuroscience $\quad 0270-6474 / 02 / 223386-06 \$ 15.00 / 0$ mitter L-glutamate, as well as by electrical stimulation. This increased CBS activity is regulated by a pathway involving $\mathrm{Ca}^{2+} /$ calmodulin. In addition, LTP is altered in CBS knock-out mice. These observations suggest that $\mathrm{H}_{2} \mathrm{~S}$ is produced by $\mathrm{CBS}$ in response to neuronal excitation and that it may regulate some aspects of synaptic activity.

Key words: hydrogen aulfide; neuromodulator; calcium ion; calmodulin; neurona' ¿xcitâ, n; glutamate; LTP

are activated $\mathrm{L}_{\mathrm{L}-\mathrm{g}}$ tam. (Garthwaite et al., 1988; Bredt and Snyder, 1990) Te reg lation of CO production by neuronal excitati is not de stood (Baranano et al., 2001).

CB, kn k-out nice have been established (Watanabe et al., Anima homozygous for the CBS mutant gene are born at he expected frequency from matings of heterozygotes, but a najority $f$ them die within 5 weeks after birth. They have less b. Iy wh than the wild-type mice, but the weight and morhology of the brain is normal (Watanabe et al., 1995; our unpublished observation). We used the CBS knock-out mice to show that $\mathrm{CBS}$ produces the endogenous $\mathrm{H}_{2} \mathrm{~S}$ in the brain. We also found a novel regulation for $\mathrm{H}_{2} \mathrm{~S}$ production by $\mathrm{Ca}^{2+}$ / calmodulin and determined the 19 amino acid calmodulin binding domain in CBS. In addition, it is shown that L-glutamate, as well as electrical stimulation, enhances the production of $\mathrm{H}_{2} \mathrm{~S}$ from brain slices and that LTP is altered in CBS knock-out mice. These observations suggest that endogenous $\mathrm{H}_{2} \mathrm{~S}$ is produced when CBS is activated by the $\mathrm{Ca}^{2+}$ influx, which occurs with neuronal excitation, and that $\mathrm{H}_{2} \mathrm{~S}$ may function as a neuromodulator or transmitter (Baranano et al., 2001).

\section{MATERIALS AND METHODS}

Determination of genotype by PCR. CBS knock-out heterozygous mice were purchased from The Jackson Laboratory (Bar Harbor, ME). Exons 3 and 4 were deleted and exchanged with the neomycin-resistant gene in knock-out mice (Watanabe et al., 1995). Genomic DNA was isolated from mouse tails and amplified by PCR with three primers: 5'-CGG ATG ACC TGC ATT CAT CT-3'; 5'-GAA GTG GAG CTA TCA GAG CA-3'; and 5'-GAG GTC GAC GGT ATC GAT A-3'.

Purification of CBS from brain homogenates. For the measurement of $\mathrm{H}_{2} \mathrm{~S}$ production, CBS was purified by calmodulin Sepharose 4B from brain homogenates. Brain homogenates in $3 \mathrm{vol}$ of Tris-buffered saline (TBS) [50 mm Tris- $\mathrm{HCl}, \mathrm{pH} 7.4,150 \mathrm{~mm} \mathrm{NaCl}, 10 \%$ glycerol, $0.2 \mathrm{~mm}$ PMSF, $1 \mathrm{~mm}$ EGTA, and protease inhibitor cocktail (Roche, Basel, Switzerland)] were centrif uged at $10,000 \times g$ for $60 \mathrm{~min}$ at $4^{\circ} \mathrm{C}$, and the supernatant was recovered. Immediately before applying to calmodulin Sepharose column, $\mathrm{CaCl}_{2}$ was added to the final concentration of $4 \mathrm{~mm}$. After washing with five bed volumes of $1 \mathrm{mM} \mathrm{CaCl}_{2}$ containing TBS, CBS was eluted with 2 mM EGTA containing TBS. The resultant eluent was dialyzed with TBS. The protein concentrations of the eluent were estimated by Protein Assay (Bio-Rad, Hercules, CA).

Brain cell suspensions. Brain cell suspensions were prepared from the brain of 8-d-old mice by a modified method described by Garthwaite et al. (1988). The fresh tissues were minced and digested with $5 \mathrm{ml}$ of 0.25 $\mathrm{mg} / \mathrm{ml}$ trypsin in $\mathrm{Ca}^{2+} / \mathrm{Mg}^{2+}$-free basic salt solution [10 mM HEPES, 
pH7.2, $150 \mathrm{~mm} \mathrm{NaCl}, 5 \mathrm{~mm} \mathrm{KCl}, 11 \mathrm{~mm}$ glucose, and 0.75\% BSA (type III; Sigma, St. Louis, MO)] at $37^{\circ} \mathrm{C}$ for $30 \mathrm{~min}$. The reaction was terminated by adding $5 \mathrm{ml}$ of $\mathrm{Ca}^{2+} / \mathrm{Mg}^{2+}$-free basic salt solution containing $40 \mu \mathrm{g} / \mathrm{ml}$ deoxyribonuclease I and $0.25 \mathrm{mg} / \mathrm{ml}$ soy bean trypsin inhibitor (Sigma). After washing, cells were resuspended at the density of $10^{5}$ cells $/ \mathrm{ml}$. After $1 \mathrm{hr}$ of preincubation at $37^{\circ} \mathrm{C}$ in air, $100 \mu \mathrm{l}$ of cell suspensions were transferred to a $1.5 \mathrm{ml}$ microtube, and agonists or antagonists were applied. Stimulation was terminated by adding $2 \mu \mathrm{l}$ of $10 \mathrm{M} \mathrm{NaOH}$.

Measurement of $\mathrm{H}_{2} \mathrm{~S}$. The amounts of endogenous $\mathrm{H}_{2} \mathrm{~S}$ in the brain and $\mathrm{H}_{2} \mathrm{~S}$ produced by cell suspensions were measured by a gas chromatograph (Hoshika and Iida, 1977) (GC-14B; Shimazu, Kyoto, Japan). Briefly, 100 $\mu \mathrm{l}$ of homogenates consisting of $1 \mathrm{vol}$ of brain and $3 \mathrm{vol}$ of $10 \mathrm{~mm} \mathrm{NaOH}$ in a $1.5 \mathrm{ml}$ microtube were filled with $\mathrm{N}_{2}$ gas and sealed with parafilm (American National Can, Chicago, IL). $\mathrm{H}_{2} \mathrm{~S}$ gas was released by adding $100 \mu \mathrm{l}$ of $100 \%$ trichloro acetic acid to the tube with a $1 \mathrm{ml}$ syringe and then incubated at $37^{\circ} \mathrm{C}$ for $30 \mathrm{~min}$. Three hundred microliters of gas were removed from the reaction tube and applied to a gas chromatograph.

$\mathrm{H}_{2} \mathrm{~S}$ produced by purified CBS was measured as follows: $100 \mu \mathrm{l}$ of 50 mM Tris, $\mathrm{pH}$ 8.6, $2 \mathrm{~mm}$ pyridoxal 5' -phosphate, and $1 \mathrm{~mm}$-cysteine, with $4.6 \mu \mathrm{g}$ of total protein of purified CBS was incubated at $37^{\circ} \mathrm{C}$ for $30 \mathrm{~min}$. Concentrations of $\mathrm{Ca}^{2+}$ in the reaction mixture were determined by an ion meter (F-23; Horiba, Kyoto, Japan). The procedures to measure the amounts of $\mathrm{H}_{2} \mathrm{~S}$ released were the same as above. The quantitation of $\mathrm{H}_{2} \mathrm{~S}$ was done using NaHS as a standard.

Measurement of free L-cysteine in the brain. The amounts of L-cysteine were measured by using a reverse-phase HPLC with fluorescence detection (Waters 2690 separation module and 474 scanning fluorescence detector; Waters, Milford, MA). The brain extracts were boiled and extracted with phenol-chloroform and then centrif uged at $15,000 \times g$ for $10 \mathrm{~min}$. The supernatant was labeled by AccQ-Tag system (Waters) and applied to the HPLC. Quantitation was done with an external standard of L-cysteine.

The electrical stimulation of brain slices and the induction of LTP. For the study of $\mathrm{H}_{2} \mathrm{~S}$ production induced by electrical stimulation, slices of cerebral cortices $(300 \mu \mathrm{m})$ were prepared from the 4-week-old mice a maintained in a chamber at $30^{\circ} \mathrm{C}$ in artificial CSF (ACSF) containing ( $\mathrm{mm}$ ): $119 \mathrm{NaCl}, 2.5 \mathrm{KCl}, 2.5 \mathrm{CaCl}_{2}, 1.3 \mathrm{MgSO}_{4}, 1 \mathrm{NaH}_{2} \mathrm{~Pa} 26$. $\mathrm{NaHCO}_{3}$, and 11 glucose (bubbled with $95 \% \mathrm{O}_{2}-5 \% \mathrm{CO}_{2} \mathrm{Ab}$ olar stimulating electrode was placed at the white matter, anc our $1.1 \mathrm{~Hz}$ pulses (100 $\mu \mathrm{sec}$ duration) at $200 \mathrm{msec}$ intervals and $3 \mathrm{~V}$ o cimulus intensity were applied for $30 \mathrm{sec}$ or $1 \mathrm{~min}$. After stip ration, ch slice was transferred into a $1.5 \mathrm{ml}$ microtube, and the am of $\mathrm{H}_{\Delta}$, was measured.

For LTP experiments, hippocampal slice $(400 \mu \mathrm{m})$ wo prepared from the 12- to 16-d-old CBS knock-out ce ar the wild-type litter mates and maintained in a chamber at $30^{\circ} \mathrm{C} . \mathrm{SF}{ }^{1}$ at contained 10 $\mu \mathrm{M}$ bicuculline to suppress inhibito nap re onses. A bipolar stimulating electrode was placed in stra $\mathrm{um}$ rad um in the CA1/CA2 border region, and the evoked $\mathrm{EK} \mathrm{N}$ w ellularly recorded from the stratum radiatum in the CA1 reg with a glass capillary microelectrode (1-5 M $\Omega$ ) filled with $0.5 \mathrm{~m} \mathrm{NaC}$ A single test stimulation (100 $\mu \mathrm{sec})$ was applied at intervals of 10 sec. The initial EPSP slopes of $0.15-0.20 \mathrm{mV} / \mathrm{msec}$ were used. To induce LTP, five sets with $10 \mathrm{sec}$ intervals of theta-burst stimulation (10 bursts of four pulses at $100 \mathrm{~Hz}$ with $200 \mathrm{msec}$ interburst intervals) were applied. Changes in field potential were recorded with an Axopatch 200A amplifier (Axon Instruments, Foster City, CA).

\section{RESULTS}

\section{CBS produces the endogenous brain $\mathrm{H}_{2} \mathrm{~S}$}

Relatively high endogenous levels of brain $\mathrm{H}_{2} \mathrm{~S}$ have been measured in rats, humans, and bovine (Goodwin et al., 1989; Warenycia et al., 1989; Savage and Gould, 1990), and $\mathrm{H}_{2} \mathrm{~S}$ production from L-cysteine in brain homogenates is suppressed by CBSspecific inhibitors, such as hydroxylamine and aminooxyacetate, and is increased by the CBS activator SAM (Abe and Kimura, 1996). Based on these observations, we proposed that CBS is an enzyme that produces endogenous $\mathrm{H}_{2} \mathrm{~S}$ in the brain. A critical experiment to support the hypothesis is to measure the endogenous levels of $\mathrm{H}_{2} \mathrm{~S}$ in the brains of CBS knock-out mice. Although the homozygotes of CBS knock-out mice show growth retardation
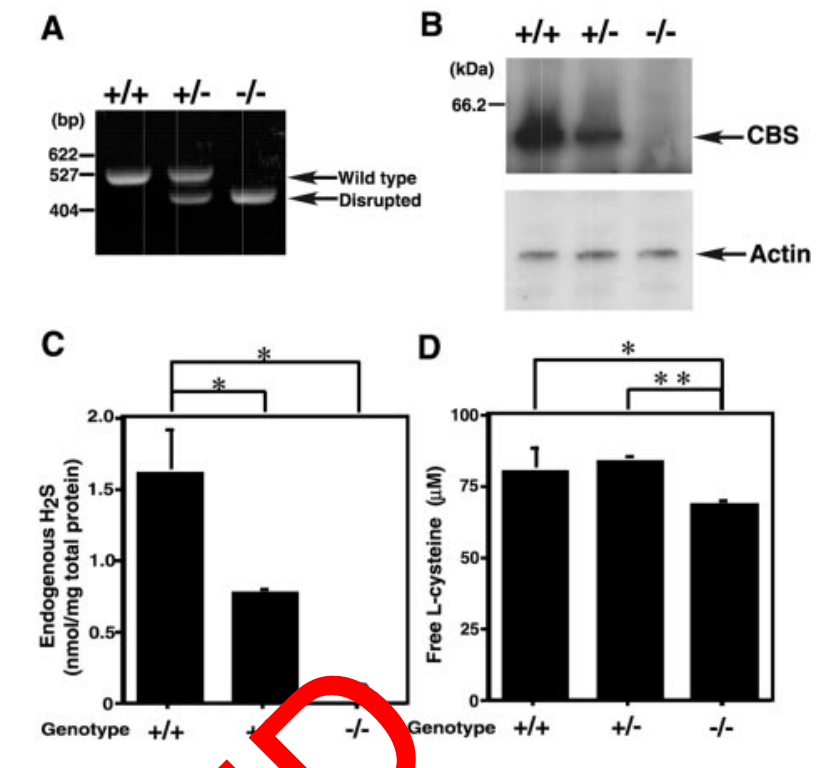

Figure 1. Brains CBS k ck- 4 mice do not contain endogenous $\mathrm{H}_{2} \mathrm{~S}$. $A$, Determinat of theno of CBS knock-out mice by PCR. PCR amplificatio w ee primers gave fragments of $500 \mathrm{bp}$ for the wild type and $40 \mathrm{bp}$ fo, the dion of CBS levels in the a by West blot analysis. Protein $(15 \mu \mathrm{g})$ obtained from the brain homog ates of homozygous $(-/-)$ and heterozygous $(+/-)$ CBS $\mathrm{k}$ out and he wild-type $(+/+)$ mice were analyzed by Western lotting with antibodies against $\mathrm{CBS}$ and actin. $C$, Determination of ndogeno $\mathrm{H}_{2} \mathrm{~S}$ levels in the brain. Endogenous $\mathrm{H}_{2} \mathrm{~S}$ levels in the brains homoz gous $(-/-)$ and heterozygous $(+/-)$ CBS knock-out mice and the $1+/+)$ were determined by gas chromatography. $D$, Endoguns L-cysteine levels in the brain. Endogenous L-cysteine levels in the brains used for $C$ were determined by HPLC. Data in $C$ and $D$ represent the mean \pm SEM of five experiments for the heterozygous mice and the wild type and three experiments for the homozygous CBS knock-out mice. ${ }^{*} p<0.05 ;{ }^{*} p<0.001$; Student's $t$ test.

(Watanabe et al., 1995), the morphology and weights of their brains are normal (data not shown). The genotypes of CBS knock-out mice were determined by PCR and confirmed by Western blot analysis (Fig. $1 A, B$ ). Because CBS knock-out mice have a high incidence of death during the third and fourth postnatal weeks (Watanabe et al., 1995), 2-week-old mice were used to measure endogenous brain $\mathrm{H}_{2} \mathrm{~S} . \mathrm{H}_{2} \mathrm{~S}$ in the brains of the homozygous CBS knock-out mice was under detectable levels (Fig. $1 C)$. The $\mathrm{H}_{2} \mathrm{~S}$ level of the heterozygous mice $(0.76 \pm 0.04$ $\mathrm{nmol} / \mathrm{mg}$ protein; $n=5$ ) was less than one-half of the wild-type mice $(1.60 \pm 0.32 \mathrm{nmol} / \mathrm{mg}$ protein; $n=5 ; p<0.05$ by the Student's $t$ test). Because the above data could be attributable to differences in substrate concentration, the amounts of L-cysteine in the brains of CBS knock-out mice were measured and compared with those of the wild type. Although the levels of L-cysteine in homozygous $(68.0 \pm 2.4 \mu \mathrm{M} ; n=5)$ CBS knock-out mice are less than those of the wild-type $(79.8 \pm 8.8 \mu \mathrm{M} ; n=5$; $p<0.05$ by the Student's $t$ test) and heterozygous $(83.1 \pm 2.8 \mu \mathrm{M}$; $n=5 ; p<0.001$ ) mice, the lack of brain $\mathrm{H}_{2} \mathrm{~S}$ in CBS knock-out mice cannot be attributable to the slightly lower level of L-cysteine (Fig. 1D). These observations clearly show that CBS produces the endogenous $\mathrm{H}_{2} \mathrm{~S}$ in the brain.

\section{Regulation of CBS activity by $\mathbf{C a}^{2+} /$ calmodulin}

CBS is dependent on pyridoxal 5'-phosphate and heme, and its activity is enhanced by SAM (Finkelstein et al., 1975; Kery et al., 1994). No other regulators for this enzyme have been found. CBS 
Figure 2. $\mathrm{H}_{2} \mathrm{~S}$ production by $\mathrm{CBS}$ is regulated by $\mathrm{Ca}^{2+} /$ calmodulin. $A$, A comparison of a consensus sequence of calmodulin binding domain of CBS with other calmodulin binding proteins. CaM-KII, Calmodulin-dependent kinase II; CaM-KI, calmodulin-dependent kinase I; MARCKS, myristoylated alanine-rich protein kinase C substrate; HSP84, heat shock protein $84 \mathrm{kDa}$. $B$, Immunoprecipitation assay for calmodulin binding to CBS. Ten milligrams of brain homogenate were immunoprecipitated with an antibody against CBS and analyzed by Western blotting with antibodies against CBS and calmodulin. Actin in the lysate served as a control. $C, \mathrm{H}_{2} \mathrm{~S}$ production from purified CBS is regulated by $\mathrm{Ca}^{2+}$ and calmodulin. Protein $(4.6 \mu \mathrm{g})$ of CBS purified by calmodulin Sepharose $4 \mathrm{~B}$ column was incubated with $1 \mathrm{~mm}$ cysteine and $2 \mathrm{~mm}$ pyridoxal $5^{\prime}$-phosphate in the presence or absence of $6 \mu \mathrm{M} \mathrm{Ca}^{2+}$ and/or $1 \mu \mathrm{M}$ calmodulin, and $\mathrm{H}_{2} \mathrm{~S}$ production was measured. $R M$, Reaction mixture alone; $E F$, enzyme fraction alone. ${ }^{*} p<0.01$; ${ }^{*} p<<0.001$; Student's $t$ test. $D, E, \mathrm{Ca}^{2+}(D)$ or calmodulin $(E)$ concentration-dependent $\mathrm{H}_{2} \mathrm{~S}$ production from purified $\mathrm{C}$ Sepharose 4B was incubated with $1 \mathrm{~mm}$ cysteine and $2 \mathrm{~mm}$ pyridoxal $5^{\prime}$-phosphate in the presen $(E)$, and the production of $\mathrm{H}_{2} \mathrm{~S}$ with different concentrations of $\mathrm{Ca}^{2+}(D)$ or calmodulin calmodulin inhibitors. Purified CBS $(4.6 \mu \mathrm{g})$ was incubated with $1 \mathrm{~mm}$ cysteine and $2 \mathrm{~mm} \mathrm{p}$ and $6 \mu \mathrm{M} \mathrm{Ca}^{2+}$, and the effects of trifluoroperazine $(\bullet)$ or $\mathrm{W}-13(\bigcirc)$ on $\mathrm{H}_{2} \mathrm{~S}$ production $\mathrm{y}$ of five experiments.
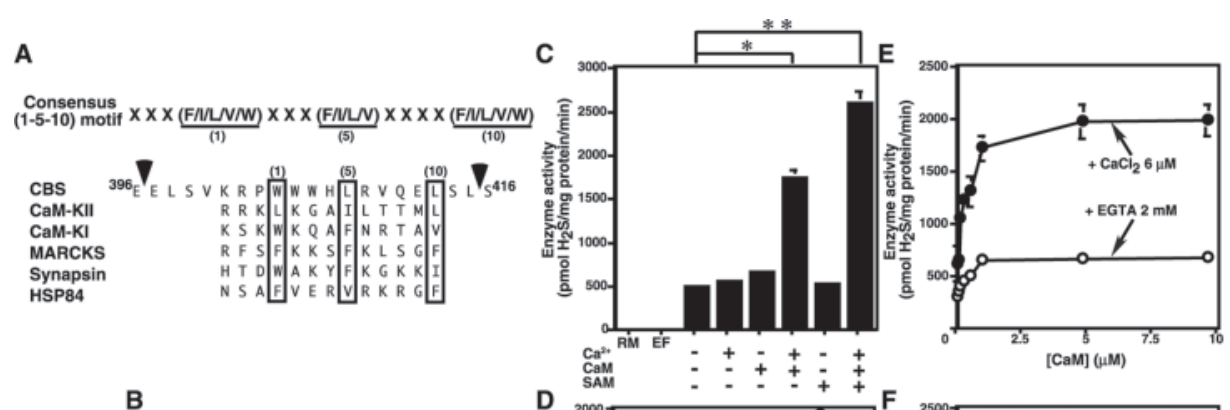

B

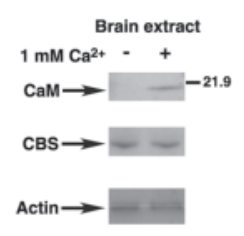

contains a consensus sequence conserved in calmodulin binding proteins (Rhoads and Friedberg, 1997) (Fig. 2A). Therefore, the potential interaction between CBS and calmodulin was examined by immunoprecipitation assays with brain extracts. Because calmodulin binding is $\mathrm{Ca}^{2+}$ dependent, brain extracts were imm noprecipitated with an antibody against CBS in the presence o absence of $1 \mathrm{~mm} \mathrm{Ca}^{2+}$. Calmodulin coimmunoprecipi ated vith CBS in the presence of $1 \mathrm{mM} \mathrm{Ca}^{2+}$ but not in the gbse $\mathrm{Ca}^{2+}$ (Fig. 2B). CBS was not coimmunopreci, tates vith an unrelated antibody against focal adhesion $\mathrm{k}$ in thame experiment (data not shown). This obseryation sh ys that CBS interacts with calmodulin in the presen of $\mathrm{Ca}^{2+}$.

Because CBS interacts with calmo $\operatorname{lin} A_{2} \mathrm{~S}$ production by CBS could be regulated by $\mathrm{Ca}^{2+} \mathrm{mmo}$ lin. $\mathrm{T}$ examine this possibility, $\mathrm{H}_{2} \mathrm{~S}$ production by $\mathrm{C} S \mathrm{~S}$ p ified m brain homogenates by calmodulin Sepharos $4 \mathrm{~B}$ ography was investigated. CBS was purified 45-fold determined by the ratio of activity to protein relative to the cru brain homogenates. $\mathrm{H}_{2} \mathrm{~S}$ was then measured in the presence of $1 \mathrm{~mm}$ L-cysteine and $2 \mathrm{mM}$ pyridoxal $5^{\prime}$-phosphate, plus or minus $0.6 \mu \mathrm{M} \mathrm{Ca}{ }^{2+}$ or $1 \mu \mathrm{M}$ calmodulin. In the presence of $\mathrm{Ca}^{2+}$ and calmodulin, CBS produced $\mathrm{H}_{2} \mathrm{~S}$ at a rate 3.5 times greater than those without $\mathrm{Ca}^{2+}$ and calmodulin (Fig. $2 C)(p<0.01$ by the Student's $t$ test). In the presence of SAM, the enhanced CBS activity by $\mathrm{Ca}^{2+}$ and calmodulin was potentiated (Fig. $2 C)(p<0.001)$. Calmodulin or SAM alone very weakly activated the production of $\mathrm{H}_{2} \mathrm{~S}$, but $\mathrm{Ca}^{2+}$ alone did not have any effect on CBS activity. These observations show that CBS is regulated by $\mathrm{Ca}^{2+} /$ calmodulin.

The minimal $\mathrm{Ca}^{2+}$ concentration required for the maximal activation of CBS was determined with purified CBS in the presence of $1 \mu \mathrm{M}$ calmodulin. $\mathrm{Ca}^{2+}$ potentiates $\mathrm{H}_{2} \mathrm{~S}$ production in the presence of calmodulin, with an $\mathrm{ED}_{50}$ value of $290 \mathrm{nM}$, whereas $\mathrm{H}_{2} \mathrm{~S}$ production remained at the basal level in the absence of calmodulin (Fig. 2D). The dose-response curve of calmodulin required for CBS activity was also determined in the presence of $6 \mu \mathrm{M} \mathrm{Ca}^{2+}$. Calmodulin potentiates $\mathrm{H}_{2} \mathrm{~S}$ production with the $\mathrm{ED}_{50}$ of $140 \mathrm{~nm}$ (Fig. $2 \mathrm{E}$ ). To confirm that $\mathrm{H}_{2} \mathrm{~S}$ produc- tion ${ }^{-1} \mathrm{CBS}$ quires $\mathrm{Ca}^{2+} /$ calmodulin, the effect of calmodulin hhibitors on $\mathrm{H}_{2} \mathrm{~S}$ production from purified CBS was examined. A otent $c_{5}$ modulin inhibitor, trifluoroperazine, suppressed $\mathrm{H}_{2} \mathrm{~S}$ p. duct $n$, with $\mathrm{IC}_{50}$ value of $8 \mu \mathrm{M}$ (Fig. $2 F$ ). A specific calmod1) in hibitor, W-13, suppressed $\mathrm{H}_{2} \mathrm{~S}$ production, with an $\mathrm{IC}_{50}$ varue of $51 \mu \mathrm{M}$ (Fig. $2 F$ ). Those observations confirm that $\mathrm{H}_{2} \mathrm{~S}$ production by CBS is regulated by $\mathrm{Ca}^{2+} /$ calmodulin.

\section{Calmodulin binding domain in CBS}

The above observations show that CBS produces endogenous $\mathrm{H}_{2} \mathrm{~S}$ in the brain and that CBS is regulated by $\mathrm{Ca}^{2+} /$ calmodulin. To determine the $\mathrm{Ca}^{2+} /$ calmodulin regulatory domain within CBS, deletion mutants of CBS was prepared by transfecting COS-7 cells with expression plasmids containing mutant CBS cDNAs. The mutant (1-415), which has the C-terminal 141 amino acids of the wild-type CBS deleted (Kery et al., 1998), contains a consensus sequence for calmodulin binding (Fig. 2A), but the mutant (1-396), lacking the C-terminal 160 amino acids, is deficient in the consensus sequence. These mutants produced by COS-7 cells are shown in Figure $3 A$.

To determine whether or not the 19 amino acid sequence that contains the calmodulin binding consensus sequence interacts with calmodulin, an immunoprecipitation experiment was performed with lysates of COS-7 cells containing the wild-type CBS, mutant (1-415) or mutant (1-396). Lysates of COS-7 cells were immunoprecipitated with the antibody against CBS, and Western blot analysis was performed with the antibody against calmodulin. Both the wild type and mutant (1-415) coimmunoprecipitated with calmodulin, but the mutant (1-396) did not (Fig. 3B). These data show that the 19 amino acid sequence of CBS is required for the interaction with calmodulin.

Because CBS interacts with calmodulin at a 19 amino acid consensus sequence, it was asked whether this consensus sequence is critical for the regulation of $\mathrm{H}_{2} \mathrm{~S}$ production. Lysates of COS-7 cells containing the wild-type or CBS mutants were incubated with $1 \mathrm{~mm}$ L-cysteine and $2 \mathrm{~mm}$ pyridoxal $5^{\prime}$-phosphate in the presence or absence of $0.6 \mu \mathrm{M} \mathrm{Ca}^{2+} / 1 \mu \mathrm{M}$ calmodulin, and 
A

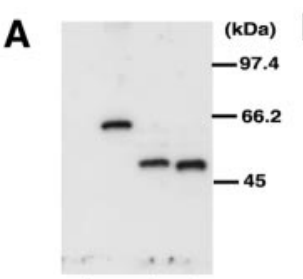

B

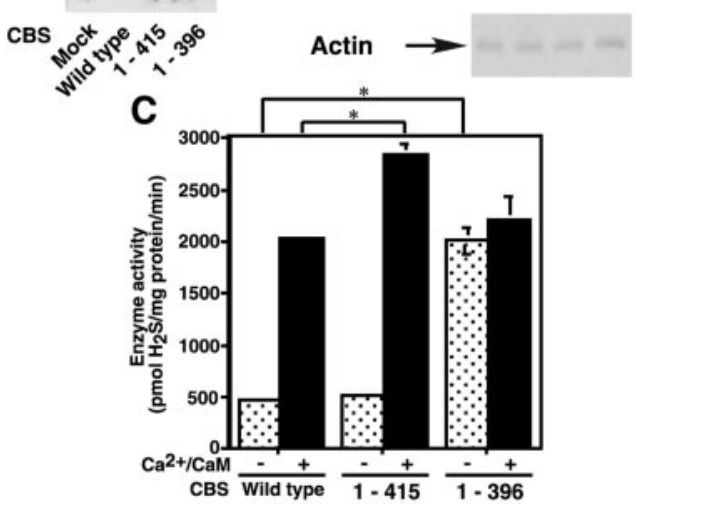

Figure 3. Determination of the calmodulin binding domain of CBS. $A$, Western blot analysis of deletion mutants of CBS. COS-7 cells were transiently transfected with expression plasmids containing the wild-type CBS (amino acid 1-556), mutant (1-415), and mutant (1-396). The cell lysates were analyzed by Western blotting with the antibody against CBS. $B$, Immunoprecipitation assay for calmodulin ( $\mathrm{CaM})$ binding to CBS mutants. Lysates $(1.5 \mathrm{mg})$ described in $A$ were immunoprecipitated with an antibody against CBS and analyzed by Western blotting with antibodies against CBS and calmodulin. Actin in the lysates served as control. Note that CBS mutants (1-415) and (1-396) appeared with a strong ba of $\mathrm{IgG}$ heavy chain. $C, \mathrm{Ca}^{2+} /$ calmodulin-dependent production of $\mathrm{H}$ s from the wild-type and mutant CBS. Protein $(1.5 \mu \mathrm{g})$ obtained from eac cell lysate described in $A$ was incubated with $1 \mathrm{~mm} \mathrm{~L}$-cysteine 100 pyridoxal 5 '-phosphate in the presence or absence of $\left.6 \mu, \mathrm{Ca}^{2+}\right) \mu \mathrm{M}$ calmodulin, and the production of $\mathrm{H}_{2} \mathrm{~S}$ was measured. Th the mean \pm SEM of five experiments. ${ }^{*} p<0.01$; St

\section{(1)}

$\mathrm{H}_{2} \mathrm{~S}$ production was determined. The my ant (1-3), which is deficient in 19 amino acid consensus se aenced produced $\mathrm{H}_{2} \mathrm{~S}$ at almost the same rate as the wild-typ azyme even in the absence of $\mathrm{Ca}^{2+} /$ calmodulin (Fig $-0,0.0$ by the Student's $t$ test). The wild type and mut it $(1-15)$ pruduced only a basal rate of $\mathrm{H}_{2} \mathrm{~S}$ in the absence of $\mathrm{C}^{2}$ calmodulin. These observations suggest that the 19 amino acid quence suppresses the CBS activity in the absence of $\mathrm{Ca}^{2+} /$ calmodulin. Once calmodulin binds to the sequence, CBS is released from the suppressed state to become active. A similar model has been proposed for the regulation of CBS activity by SAM (Shan et al., 2001).

\section{$\mathrm{H}_{2} \mathrm{~S}$ production is enhanced by L-glutamate, $\mathrm{Ca}^{2+}$ ionophore, and electrical stimulation}

Because $\mathrm{H}_{2} \mathrm{~S}$ production by CBS is regulated by $\mathrm{Ca}^{2+} /$ calmodulin, $\mathrm{H}_{2} \mathrm{~S}$ production may be controlled by neuronal activity. To examine this possibility, we prepared brain cell suspensions (Garthwaite et al., 1988) and measured $\mathrm{H}_{2} \mathrm{~S}$ production induced by the application of L-glutamate and its analogues. The production of $\mathrm{H}_{2} \mathrm{~S}$ was greatly enhanced by stimulation with L-glutamate ( $p<0.001$ by the Student's $t$ test), NMDA $(p<0.01)$, or AMPA $(p<0.001)$ in the presence of $2 \mathrm{mM} \mathrm{Ca}^{2+}$ (Fig. 4A). The $\mathrm{Ca}^{2+}$-dependent activation by NMDA requires L-glycine but is suppressed in the presence of $\mathrm{Mg}^{2+}$. The effect of NMDA was inhibited by an NMDA-specific inhibitor, AP-5, and that of AMPA was inhibited by an AMPA-specific inhibitor, CNQX (Fig. 4A). These observations indicate that $\mathrm{H}_{2} \mathrm{~S}$ is produced when
A
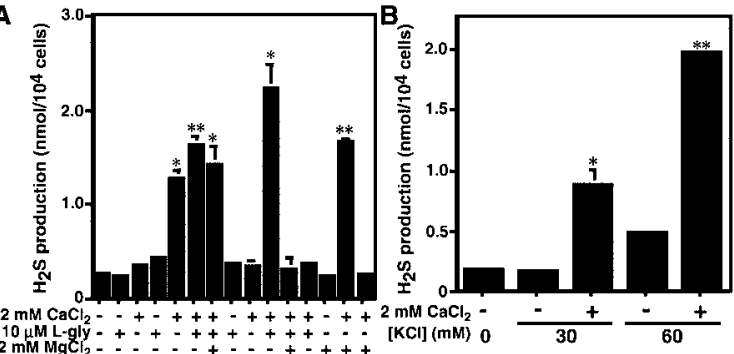

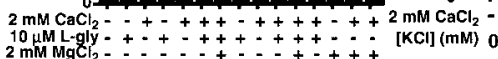

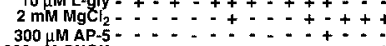

$300 \mu M$ CNQX

Excitatory a

$\frac{-1-g / U}{C}$

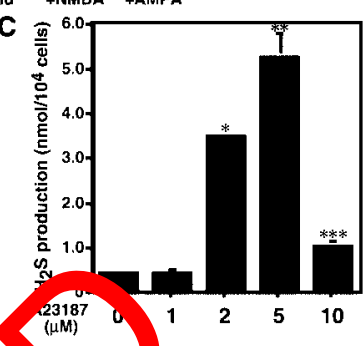

Figure 4. $\mathrm{H}_{2} \mathrm{~S} \mathrm{p}$ duction $\mathrm{ep}$ anced by L-glutamate, depolarization, and $\mathrm{Ca}^{2+}$ ion nore, $\mathrm{L}-\mathrm{O}$, amate and its analogs enhance the production of $H_{2} \mathrm{~S}$. $\mathrm{e}^{\mathrm{N}}$, at $1>10^{4}$ in $100 \mu \mathrm{l}$ of cell suspensions obtained from mor cereb, cort es were incubated with glutamate analogs and their 1 for $5 \mathrm{~min}$, and the production of $\mathrm{H}_{2} \mathrm{~S}$ was measured by s chromatography. ${ }^{*} p<0.01$; ${ }^{*} p<<0.001$; Student's $t$ test. $B$ mbrane a olarization enhances the production of $\mathrm{H}_{2} \mathrm{~S}$. K ${ }^{+}$at 30 or $0 \mathrm{~mm}$ was applied to brain cell suspensions in the presence or absence of $\mathrm{mm} \mathrm{Ca}$ at $37^{\circ} \mathrm{C}$ for $5 \mathrm{~min}$, and the production of $\mathrm{H}_{2} \mathrm{~S}$ was measured. $<0.05 * *<0.001$; Student's $t$ test. $C, \mathrm{H}_{2} \mathrm{~S}$ production in brain cell susp ons induced by $\mathrm{Ca}^{2+}$ influx. $\mathrm{H}_{2} \mathrm{~S}$ produced in brain cell suspenns by the application of A23187 was measured. * $p<0.001 ;{ }^{*} p<0.01$; $* * p<0.05$; Student's $t$ test. All data in $A-C$ represent the mean \pm SEM of five experiments.

$\mathrm{Ca}^{2+}$ enters into the cells by the activation of at least two classes of ionotropic glutamate receptors.

When the neuronal membrane is depolarized, voltageactivated $\mathrm{Ca}^{2+}$ channels are opened and $\mathrm{Ca}^{2+}$ enters into the cells (Llinas, 1988). Because high concentrations of $\mathrm{K}^{+}$depolarize the membrane, the effect of high concentrations of $\mathrm{K}^{+}$on the $\mathrm{H}_{2} \mathrm{~S}$ production was examined using brain cell suspensions. In the presence of $2 \mathrm{~mm} \mathrm{Ca}^{2+}, 30$ ( $p<0.05$ by the Student's $t$ test) and $60(p<0.001) \mathrm{mM} \mathrm{K}^{+}$greatly enhanced $\mathrm{H}_{2} \mathrm{~S}$ production (Fig. $4 B$ ). To confirm that $\mathrm{H}_{2} \mathrm{~S}$ production from brain cell suspensions was induced by $\mathrm{Ca}^{2+}$ influx, the effect of the $\mathrm{Ca}^{2+}$ ionophore A23187 on $\mathrm{H}_{2} \mathrm{~S}$ production was examined. Concentrations up to $5 \mu \mathrm{M}$ A23187 dose-dependently potentiate $\mathrm{H}_{2} \mathrm{~S}$ production $(p<$ 0.01 by the Student's $t$ test), whereas $10 \mu \mathrm{M}$ A23187 showed weaker potentiation (Fig. $4 C)(p<0.05)$. These observations suggest that $\mathrm{H}_{2} \mathrm{~S}$ production is induced by $\mathrm{Ca}^{2+}$ entry after the depolarization of the membrane.

Based on the above observations, it was asked whether $\mathrm{H}_{2} \mathrm{~S}$ is produced from slices of cerebral cortices by L-glutamate and electrical stimulation. L-Glutamate at $100 \mu \mathrm{M}$ enhances $\mathrm{H}_{2} \mathrm{~S}$ production three times above the basal level (Fig. $5 A)(p<0.05$ by the Student's $t$ test). Electrical stimulation for 0.5 and $1 \mathrm{~min}$ causes $\mathrm{H}_{2} \mathrm{~S}$ production at approximately twice $(1.62 \pm 0.40$ $\mathrm{nmol} / \mathrm{mg}$ protein; $n=3 ; p<0.05)$ and three $(2.18 \pm 0.50$ $\mathrm{nmol} / \mathrm{mg}$ protein; $n=3 ; p<0.05)$ times the basal level $(0.76 \pm$ $0.04 \mathrm{nmol} / \mathrm{mg}$ protein; $n=3$ ), respectively, whereas longer stimulation for 2 min did not effectively increase $\mathrm{H}_{2} \mathrm{~S}$ production $(p<$ 0.01) (Fig. 5B). These observations show that $\mathrm{H}_{2} \mathrm{~S}$ is produced when neurons in slices are excited by electrical stimulation. 


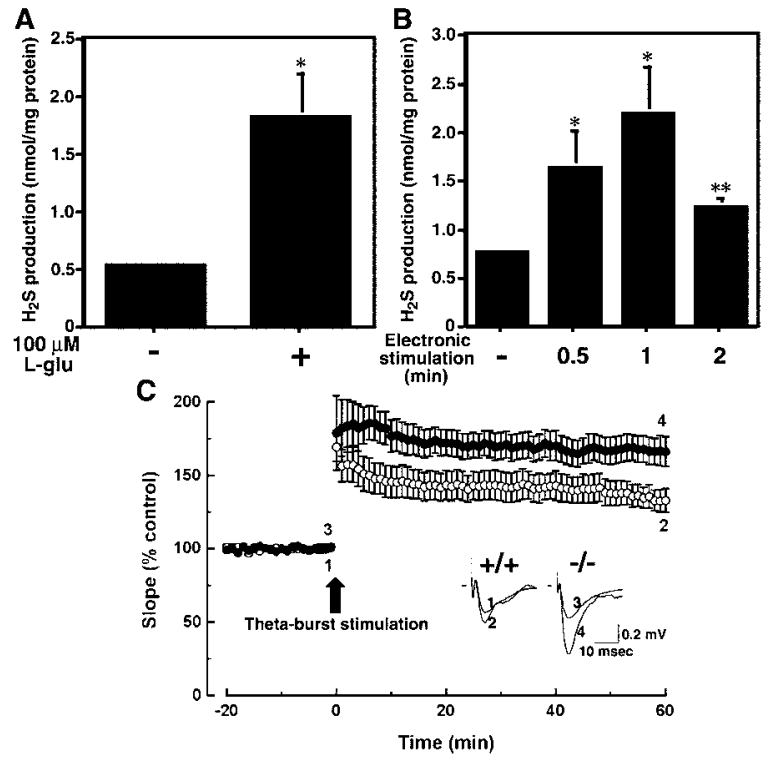

Figure 5. The production of $\mathrm{H}_{2} \mathrm{~S}$ and the induction of LTP in brain slices. $A, B$, The production of $\mathrm{H}_{2} \mathrm{~S}$ induced by L-glutamate and electrical stimulation. $\mathrm{H}_{2} \mathrm{~S}$ produced in the slices of cerebral cortices by the application of $100 \mu \mathrm{M}$ L-glutamate $(A)$ and by electrical stimulation for $0,0.5$, 1 , and $2 \min (B)$ was measured. Data are represented as the mean \pm SEM of three experiments. ${ }^{*} p<0.05$; ${ }^{*} p<<0.01$; Student's $t$ test. $C$, LTP is altered in the absence of $\mathrm{H}_{2} \mathrm{~S}$. Five sets of theta-burst stimulation $(10$ trains of 4 pulses of $100 \mu \mathrm{sec}$ each at $200 \mathrm{msec}$ intervals) applied at $10 \mathrm{sec}$ intervals to hippocampal slices of CBS knock-out mice $(\bullet)$ and the wild-type mice $(\bigcirc)$. The field EPSP slopes were expressed as the percentage of baseline values before stimulation. Representative records at times denoted by the numbers are shown as insets. The mean field EPS slope $(166.1 \pm 10.1 \% ; n=9) 60 \mathrm{~min}$ after stimulation in the slig CBS knock-out mice is significantly different $(p<0.037$; Student', test rom those in the wild-type mice $(132.1 \pm 9.3 \% ; n=6)$.

\section{LTP is altered in CBS knock-out mic}

Because exogenously applied $\mathrm{H}_{2} \mathrm{~S}$ modif es the induction of LTP in hippocampal slices (Abe and Kin ra, 996), we examined whether or not LTP is altered in $\mathrm{K}$ ock-at mice. Thetaburst stimulation was applied to nduc LTP arent et al., 1998), and changes in the slopes of E SP wom easured. After stimulation, the augmented field EPS lope in CBS knock-out mice gradually decreased and reached a planeau of $166.1 \pm 10.1 \%(n=$ 9 ) of that before stimulation (Fig. $5 C$ ). In contrast, in slices of wild-type mice, the field EPSP slope reached a plateau of $132.1 \pm$ $9.3 \%(n=6)$ of that before stimulation (Fig. $5 C)$. The statistical difference between EPSP slopes at 60 min after stimulation in CBS knock-out mice and the wild-type mice is significant $(p<$ 0.037 by the Student's $t$ test). These observations show that LTP is altered in the absence of $\mathrm{H}_{2} \mathrm{~S}$ and suggest the involvement of $\mathrm{H}_{2} \mathrm{~S}$ in synaptic activity.

\section{DISCUSSION}

The enzymatic activity of CBS has two metabolic outcomes (Mudd et al., 1989; Warenycia et al., 1989). Most studies have been devoted to a pathway in which CBS catalyzes the reaction with substrate homocysteine to produce cystathionine (Mudd et al., 1989). In another pathway, CBS catalyzes the reaction with L-cysteine as a substrate to produce $\mathrm{H}_{2} \mathrm{~S}$ and pyruvate (Stipanuk and Beck, 1982). The latter reaction had not been studied in the nervous system until we proposed that CBS can produce endogenous $\mathrm{H}_{2} \mathrm{~S}$ in the brain (Abe and Kimura, 1996). Because the activities of CBS in both metabolic pathways are regulated by SAM (Finkelstein et al., 1975; Abe and Kimura, 1996), a model for CBS regulation has been proposed in which the C-terminal domain of CBS bends to and covers its own catalytic domain, suppressing enzymatic CBS activity. Once SAM binds to the regulatory domain of $\mathrm{CBS}$, a conformational change occurs that frees the catalytic domain, and CBS becomes active (Shan et al., 2001). Our present observations suggest that a similar mechanism may also function in the regulation of $\mathrm{CBS}$ by $\mathrm{Ca}^{2+} /$ calmodulin. In the absence of $\mathrm{Ca}^{2+} /$ calmodulin, the $\mathrm{C}$-terminal domain may cover the catalytic domain, and CBS activity remains at a basal level. When $\mathrm{Ca}^{2+} /$ calmodulin binds to the 19 amino acid sequence, the catalytic domain is exposed by opening of the C-terminal domain, and CBS becomes active. This model is supported by our observation that the CBS mutant (1-396), which is deficient in the 19 amino acid $\mathrm{Ca}^{2+} /$ calmodulin binding sequence, is constantly active, even in the absence of $\mathrm{Ca}^{2+} /$ calmodulin (Fig. 3C).

Physiological basal once rations of $\mathrm{H}_{2} \mathrm{~S}$ applied exogenously with a weak tetanic imulatio, which by itself does not induce LTP, facilitate $t^{\prime} \mathrm{C}$ ind tion f LTP (Abe and Kimura, 1996). The present ady s ows LTP is augmented in CBS knockout mice $\mathrm{Fl}_{5}$, . Ph siological basal concentrations of $\mathrm{H}_{2} \mathrm{~S}$ enhance the $\mathrm{N}$ D receptor-mediated responses, whereas highe con entrations of $\mathrm{H}_{2} \mathrm{~S}$ specifically suppress EPSPs (Abe an- imura, 996). When $\mathrm{H}_{2} \mathrm{~S}$ is applied by superfusion, NMDA eceptors on the postsynaptic membrane may be activated before he supp ssion of EPSPs, resulting in the facilitated induction of L ve. In contrast, electrical stimulation might produce $\mathrm{H}_{2} \mathrm{~S}$ at nerve endings, which could suppress EPSPs before diffusing across the synaptic cleft to activate postsynaptic NMDA receptor. Because there is no endogenous $\mathrm{H}_{2} \mathrm{~S}$ in CBS knock-out mice, LTP must be augmented.

Although $\mathrm{H}_{2} \mathrm{~S}$ is a toxic gas, most toxicology work has been done with whole animals, and less is known about its direct effect on cells (Reiffenstein et al., 1992). Because the neuronal excitation is local and lasts only for a short time, the increase in the concentrations of $\mathrm{H}_{2} \mathrm{~S}$ might not be toxic. For example, higher concentrations of $\mathrm{H}_{2} \mathrm{~S}$ than the basal level suppress EPSPs, but this suppression is reversible (Abe and Kimura, 1996). In addition, $\mathrm{H}_{2} \mathrm{~S}$ in the brain is tightly regulated to maintain endogenous concentrations at less than the toxic levels. For example, concentrations $>10 \mu \mathrm{M} \mathrm{A} 23187$ and the electrical stimulation longer than $2 \mathrm{~min}$ did not efficiently enhance $\mathrm{H}_{2} \mathrm{~S}$ production (Figs. $4 C, 5 B$ ).

In conclusion, endogenous $\mathrm{H}_{2} \mathrm{~S}$ in the brain is produced by CBS, and the production of $\mathrm{H}_{2} \mathrm{~S}$ by $\mathrm{CBS}$ is regulated by $\mathrm{Ca}^{2+}$ / calmodulin. The production of $\mathrm{H}_{2} \mathrm{~S}$ is greatly enhanced by the activation of glutamate receptors, as well as by electrical stimulation, and the loss of $\mathrm{H}_{2} \mathrm{~S}$ alters LTP. These observations suggest that $\mathrm{H}_{2} \mathrm{~S}$ may regulate some aspects of synaptic activity.

\section{REFERENCES}

Abe K, Kimura H (1996) The possible role of hydrogen sulfide as an endogenous neuromodulator. J Neurosci 16:1066-1071.

Baranano DE, Ferris CD, Snyder SH (2001) Atypical neural messengers Trends Neurosci 24:99-106.

Bliss TVP, Collingridge GL (1993) A synaptic model of memory: longterm potentiation in the hippocampus. Nature 361:31-39.

Bredt DS, Snyder SH (1990) Isolation of nitric oxide synthetase, a calmodulin-requiring enzyme. Proc Natl Acad Sci USA 87:682-685.

Finkelstein JD, Kyle WE, Martin JJ, Pick AM (1975) Activation of cystathionine synthase by adenosylmethionine and adenosylmethionine. Biochem Biophys Res Commun 66:81-87.

Garthwaite J, Charles SL, Chess-Williams R (1988) Endotheliumderived relaxing factor release on activation of NMDA receptors 
suggests role as intercellular messenger in the brain. Nature 336: 385-388.

Goodwin LR, Francom D, Dieken FP, Taylor JD, Warenycia MW, Reiffenstein RJ, Dowling G (1989) Determination of sulfide in brain tissue by gas dialysis/ion chromatography: postmortem studies and two case reports. J Anal Toxicol 13:105-109.

Griffith OW (1987) Mammalian sulfur amino acid metabolism: an overview. Methods Enzymol 143:366-376.

Haley JE, Wilcox GL, Chapman PF (1992) The role of nitric oxide in hippocampal long-term potentiation. Neuron 8:211-216.

Hoshika Y, Iida Y (1977) Gas chromatographic determination of sulphur compounds in town gas. J Chromatogr 134:423-432.

Kery V, Bukovska G, Kraus JP (1994) Transsulfuration depends on heme in addition to pyridoxal 5'-phosphate. J Biol Chem 269: 25283-25288.

Kery V, Poneleit L, Kraus JP (1998) Trypsin cleavage of human cystathionine $\beta$-synthase into an evolutionarily conserved active core: structural and functional consequences. Arch Biochem Biophys 355: $222-232$.

Kimura H (2000) Hydrogen sulfide induces cyclic AMP and modulates the NMDA receptor. Biochem Biophys Res Commun 267:129-133.

Llinas RR (1988) The intrinsic electrophysiological properties of mammalian neurons: insights into central nervous system function. Science 242:1654-1664.

Maines MD (1988) Heme oxygenase: function, multiplicity, regulatory mechanisms, and clinical applications. FASEB J 2:2557-2568.

Mudd SH, Levy HL, Skovby F (1989) Disorders of transsulfuration. In: The metabolic basis of inherited disease (Scriver CR, Beaudet AL, Sly WS, Valle D, eds), 693-734. New York: McGraw-Hill.

O'Dell TJ, Hawkins RD, Kandel ER, Arancio O (1991) Tests of the roles of two diffusible substances in long-term potentiation: evidence for nitric oxide as a possible early retrograde messenger. Proc Natl Acad Sci USA 88:11285-11289.

Palmer RMJ, Ashton DS, Moncada S (1988) Vascular endothelial cells synthesize nitric oxide from L-arginine. Nature 333:664-666.

Parent A, Schrader K, Munger SD, Reed RR, Linden DJ, Ronnett G V (1998) Synaptic transmission and hippocampal long-term potentiation in olfactory cyclic nucleotide-gated channel type 1 null mouse. J Neurophysiol 79:3295-3301.
Reiffenstein RJ, Hulbert WC, Roth SH (1992) Toxicology of hydrogen sulfide. Annu Rev Pharmacol Toxicol 32:109-134.

Rhoads AR, Friedberg F (1997) Sequence motifs for calmodulin recognition. FASEB J 11:331-340.

Russo CD, Tringali G, Ragazzoni E, Maggiano N, Menini E, Vairano M, Preziosi P, Navarra P (2000) Evidence that hydrogen sulphide can modulate hypothalamo-pituitary-adrenal axis function: in vitro and in vivo studies in the rat. J Neuroendocrinol 12:225-233.

Savage JC, Gould DH (1990) Determination of sulfides in brain tissue and rumen fluid by ion-interaction reversed-phase high-performance liquid chromatography. J Chromatogr 526:540-545.

Schuman EM, Madison D V (1991) A requirement for the intercellular messenger nitric oxide in long-term potentiation. Science 254: $1503-1506$.

Shan X, Dunbrack RLJ, Christopher SA, Kruger WD (2001) Mutation in the regulatory domain of cystathionine $\beta$-synthase can functionally suppress patient-derived mutations in cis. Human Mol Genet 10:635-643.

Stevens CF, Wang Y (1993) Reversal of long-term potentiation by inhibitors of haem oxygenase. Nature 364:147-149.

Stipanuk MH, Beck PW (1982) Characterization of the enzymic capacity for cysteine desulphhydration in liver and kidney of the rat. Biochem J 206:267-277.

Swaroop M, Bradley K, Ohura T, Tahara T, Roper MD, Rosenberg LE, Kraus JP (1992) Rat tathionine $\beta$-synthase. J Biol Chem 267:11455-11461.

Verma A, Hirsch DJ, att CE, R nnett GV, Snyder SH (1993) Carbon monoxide: a putative vural $\mathrm{me}$ senger. Science 259:381-384.

Warenycia MW, oodwin R, I nishin CG, Reiffenstein RJ, Francom DM, Taylor S, Die en $\mathrm{P}$ 1989) Acute hydrogen sulfide poisoning: demonstratio of rective uptake of sulfide by the brainstem by measuremen of br sulfid levels. Biochem Pharmacol 38:973-981.

Watanal M, Osad I atani Y, Kimberly K, Robert R, Malinow MR, Ma a (1995) Nice deficient in cystathionine $\beta$-synthase: Animal models for ild and severe homocyst (e) inemia. Proc Natl Acad Sci ODA 92:1585 589.

huo M, Small SA, Kandel ER, Hawkins RD (1993) Nitric oxide and carbon tonoxide produce activity-dependent long-term synaptic enhancem $n t$ in hippocampus. Science 260:1946-1950. 